\title{
FAKTOR-FAKTOR YANG BERHUBUNGAN DENGAN RISIKO KEMATIAN BAYI 0-28 HARI DI KABUPATEN BIREUEN
}

\author{
Factors Related To Baby Death Risk 0-28 Days \\ In Bireuen District
}

\author{
Apriany Ramadhan Batubara*1, Fitriani² $^{2}$ \\ Dosen Akbid Munawarah, Jl. Sultan Iskandar Muda No. 18 Kota Juang, Bireuen 24251, Indonesia \\ Mahasiswa Akbid Munawarah, Jl. Sultan Iskandar Muda No. 18 Kota Juang, Bireuen 24251, Indonesia \\ *Korespondensi Penulis : aprianyramadhanbatubara@gmail.com*1, fitriosbir124@gmail.com²
}

\begin{abstract}
Abstrak
Latar Belakang : Secara global, sekitar 130 juta kelahiran terjadi setiap tahun. Diantaranya 303.000 kematian ibu, 2,6 juta bayi lahir mati dan 2,7 juta bayi meninggal dalam masa neonatal. Kematian neonatal atau yang umum disebut kematian bayi endogen adalah kematian bayi yang terjadi pada bulan pertama setelah dilahirkan, dan umumnya disebabkan oleh faktor - faktor yang dibawa anak sejak lahir, yang diperoleh dari orang tuanya pada saat konsepsi atau didapat selama kehamilan. Tujuan : Untuk mengetahui faktor - faktor yang berhubungan dengan risiko kematian bayi 0-28 hari di Kabupaten Bireuen. Metode : Jenis penelitian adalah studi analitik dengan pendekatan case control. Populasi adalah seluruh ibu yang melahirkan bayi hidup dan bayi mati usia 0-28 hari di Kabupaten Bireuen. Sampel dalam penelitian ini menggunakan Cluster Sampling yang berjumlah 30 kasus dan 30 kontrol. Data dianalisis secara univariat dan bivariat dengan menggunakan uji chi-Square pada taraf kepercayaan 95\% ( $<$ <,05). Hasil : Variabel umur ibu tidak berhubungan dengan kematian bayi 0-28 hari dengan nilai $p$-value $=0,052$ dan $\mathrm{OR}=0,113$. Variabel paritas tidak berhubungan dengan kematian bayi 0-28 hari dengan nilai $p$-value $=0,362$ dan $\mathrm{OR}=1,581$. Variabel jarak kehamilan tidak berhubungan dengan kematian bayi 0-28 hari dengan nilai $p$ value $=0,273$ dan $\mathrm{OR}=1,553$. Kesimpulan : Variabel umur ibu, paritas dan jarak kehamilan tidak berhubungan dengan kematian bayi 0-28 hari. Diharapkan kepada responden agar terus menambah informasi tentang faktor-faktor yang berisiko saat kehamilan dan persalinan untuk menghindari kematian bayi 0-28 hari.
\end{abstract}

\section{Kata kunci : : Umur Ibu, Paritas, Jarak Kehamilan, Kematian Bayi 0-28 hari}

\begin{abstract}
Background: Globally, around 130 million births occur every year. Among them 303,000 maternal deaths, 2.6 million babies were stillborn and 2.7 million babies died during the neonatal period. Neonatal death, or what is commonly called endogenous infant death, is infant mortality that occurs in the first month after birth, and is generally caused by factors that the child carries from birth, obtained from his parents at the time of conception or obtained during pregnancy. Objective: To find out factors related to the risk of infant mortality from 0-28 days in Bireuen District. Method: This type of research is an analytic study with a case control approach. The population is all mothers who give birth to live infants and dead babies aged 0-28 days in Bireuen Regency. The sample in this study used cluster sampling totaling 30 cases and 30 controls. Data were analyzed univariately and
\end{abstract}


Journal of Healthcare Technology and Medicine Vol. 5 No. 2 Oktober 2019

Universitas Ubudiyah Indonesia

e-ISSN : 2615-109X

bivariately using chi-square test at 95\% confidence level ( $p<0.05)$. Results: The maternal age variable is not related to infant mortality from 0-28 days with $p$-value $=0.052$ and $O R=$ 0.113 . The parity variable is not related to infant mortality from 0-28 days with p-value = 0.362 and $O R=1.581$. The pregnancy distance variable is not related to infant mortality from 0-28 days with p-value $=0.273$ and $O R=1.553$. Conclusion: Variable maternal age, parity and distance of pregnancy are not related to infant mortality from 0-28 days. It is expected that respondents will continue to add information about risk factors during pregnancy and childbirth to avoid infant death from 0-28 days.

\section{Keywords $\quad$ : Mother's Age, Parity, Distance of Pregnancy, Infant Death 0-28 days}

\section{PENDAHULUAN}

Menurut World Health Organization (WHO), indikator kesejahteraan suatu bangsa salah satunya diukur dari besarnya angka kematian (morbilitas). Makin tinggi angka tersebut maka makin rendah tingkat kesejahteraan suatu bangsa. Di samping menunjukan derajat kesehatan dan tingkat kesejahteraan masyarakat, angka tersebut juga menunjukan kualitas pelayanan kesehatan masyarakat (WHO,2015).

Secara global, sekitar 130 juta kelahiran terjadi setiap tahun. Diantaranya 303.000 kematian ibu, 2,6 juta bayi lahir mati dan 2,7 juta bayi meninggal dalam masa neonatal. Tahun 2015, World Health Organization (WHO) mencatat 5,9 juta (43 per 1000 kelahiran hidup) anak meninggal sebelum mencapai usia lima tahun dan sebanyak 2,7 juta bayi diantaranya meninggal selama 28 hari pertama kehidupan. Sekitar 6 juta kematian anak di bawah usia lima tahun, kematian neonatal menjadi penyebab utama yaitu sebesar $45 \%$ atau 19 kematian per kelahiran hidup. Jika dibandingkan dari tahun 1990, kematian neonatal pada tahun 2015 mengalami penurunan dari 5,1 juta menjadi 2,7 juta (WHO, 2015).

Perlu kita ketahui bersama bahwa saat ini Angka Kematian Neonatal (AKN) di Indonesia tertinggi adalah di Negara ASEAN. Berdasarkan Survey Demografi dan Kesehatan Indonesia (SDKI), di Indonesia sekarang Angka Kematian Neonatal (AKN) yaitu dari 35 per 1.000 kelahiran hidup SDKI 2002-03 menurun menjadi 24 per 1.000 kelahiran hidup (SDKI, 2017).

Angka Kematian Neonatal (AKN) di Provinsi Aceh sendiri dari tahun ke tahun mengalami penurunan seperti pada tahun 2017 jumlah Angka Kematian Neonatal (AKN) hanya 7 per 1.000 kelahiran hidup dibandingkan dengan pada tahun 2016 jumlah Angka Kematian Neonatal (AKN) yaitu 8 per 1.000 kelahiran hidup. Permasalahan pada neonatus biasanya timbul karena akibat yang spesifik terjadi pada masa neonatal, masalah ini tak hanya menimbulkan kematian tetapi juga kecatatan, kebanyakan masalah muncul karena buruknya 
Journal of Healthcare Technology and Medicine Vol. 5 No. 2 Oktober 2019

Universitas Ubudiyah Indonesia

e-ISSN : 2615-109X

kesehatan ibu, manajemen persalinan yang tidak tepat dan bersih serta kurangnya perawatan bayi baru lahir (Dinkes Aceh, 2017).

Menurut data Dinas Kesehatan (DINKES) 2018 Angka Kematian Neonatal (AKN) di Kabupaten Bireuen berjumlah 91 bayi dengan jumlah kematian terbanyak terjadi di Kecamatan Kota Juang dan Jeumpa sebanyak 10 bayi, dan terendah adalah Kecamatan Simpang Mamplam, Pandrah, Jeunib, Peusangan Selatan dan Kecamatan Makmur dengan jumlah kematian hanya 2 bayi di setiap Kecamatan (Dinkes Bireuen, 2018).

Kematian (mortalitas) merupakan salah satu faktor yang dapat mempengaruhi perubahan penduduk. Yang dimaksud dengan kematian adalah peristiwa menghilangnya tanda-tanda kehidupan secara permanen, yang bisa terjadi setiap saat setelah kelahiran (fertilitas) (Padila, 2014).

Kematian neonatal atau yang umum disebut kematian bayi endogen adalah kematian bayi yang terjadi pada bulan pertama setelah dilahirkan, dan umumnya disebabkan oleh faktor - faktor yang dibawa anak sejak lahir, yang diperoleh dari orang tuanya pada saat konsepsi atau didapat selama kehamilan (Sudariyanto, 2011).

Masa neonatal (28 hari pertama kehidupan) adalah waktu yang sangat rentan untuk kelangsungan hidup anak. Kematian neonatal menjadi semakin penting karena proporsi kematian neonatal meningkat di seluruh dunia selama 25 tahun terakhir dan mendominasi dari jumlah kematian anak dibawah usia lima tahun. Selain itu, intervensi kesehatan yang dibutuhkan untuk mengatasi penyebab utama kematian neonatal berbeda dari yang diperlukan untuk mengatasi kematian anak dibawah usia lima tahun (UNICEF, 2015).

Pada kejadian kematian bayi 0-28 hari, faktor usia ibu berpengaruh terhadap kematian bayi, bayi yang dilahirkan dari ibu berusia $<20$ tahun dan $>35$ tahun memiliki risiko kematian 7,69 kali daripada bayi yang lahir dari ibu berusia 20-35 tahun (Prabumurti, 2006).

Paritas juga berpengaruh pada kematian bayi, paritas yang berisiko untuk hamil yaitu paritas 1 dan lebih dari 5 berisiko mengalami kematian neonatal 1,89 kali lebih besar dari pada bayi yang dilahirkan ibu dengan paritas 2-4, risiko kematian neonatal yang besar pada bayi yang dilahirkan dari ibu dengan paritas 1 ini disebabkan oleh kekakuan jaringan panggul serta pengetahuan tentang perawatan kehamilan dan persalinan yang rendah, sedangkan kematian neonatal pada ibu paritas $\geq 5$ ini disebabkan oleh belum pulihnya organ reproduksi dalam menerima kehamilan (Prabumurti, 2006). 
Journal of Healthcare Technology and Medicine Vol. 5 No. 2 Oktober 2019

Universitas Ubudiyah Indonesia

e-ISSN : 2615-109X

Jarak kehamilan juga berpengaruh terhadap kematian bayi, jarak kehamilan $<2$ tahun memiliki risiko 1,94 kali terjadinya kematian dibandingkan bayi dengan jarak kehamilan $\geq 2$ tahun (Husaini, 2013).

Berdasarkan survey awal yang dilakukan oleh peneliti di Kabupaten Bireuen, dijumpai 10 ibu yang bersalin pada tahun 2018, 5 diantaranya mengalami kematian bayi pada masa neonatal, dan berdasarkan hasil wawancara terhadap 5 ibu yang mengalami kematian bayi didapatkan bahwa 2 ibu dengan umur $>35$ tahun dan 3 ibu dengan paritas 1 .

Berdasarkan uraian diatas maka peneliti tertarik melakukan penelitian untuk mengetahui Faktor Risiko Yang Memengaruhi Kematian Bayi 0-28 Hari di Kabupaten Bireuen Tahun 2019.

\section{METODE PENELITIAN}

Desain penelitian ini adalah survey analitik dengan pendekatan case control, Lokasi penelitian ini dilakukan di Kabupaten Bireuen dengan waktu penelitian dilakukan pada bulan mei s/d juni 2019. Populasi dalam penelitian ini adalah seluruh ibu yang bersalin pada tahun 2018 baik bayi hidup atau mati usia 0-28 hari di Kabupaten Bireuen berdasarkan data sekunder dari Dinas Kesehatan Bireuen. Teknik pengambilan sampel menggunakan teknik cluster sampling sebanyak 30 kasus dan 30 kontrol. Data dianalisis secara univariat dan bivariat dengan uji chi-square .

\section{HASIL PENELITIAN}

Analisis Univariat : Berdasarkan tabel 1 dapat dilihat pada kelompok kasus umur ibu yang memiliki umur 20-35 tahun sebanyak 23 orang $(38,3 \%)$ dan yang memiliki umur $>35$ tahun sebanyak 7 orang (11,7\%). Pada kelompok kontrol umur ibu yang memiliki umur 20-35 tahun sebanyak 29 orang $(48,3 \%)$ dan yang memiliki umur $>35$ tahun sebanyak 1 orang $(1,7 \%)$.

Pada kelompok kasus paritas yang primipara sebanyak 12 orang (20\%), yang multipara sebanyak 15 orang (25\%) dan grande multipara sebanyak 3 orang (5\%). Pada kelompok kontrol paritas yang primipara sebanyak 7 orang $(11,7 \%)$, yang multipara sebanyak 20 orang $(33,3 \%)$ dan grande multipara sebanyak 3 orang $(5 \%)$

Pada kelompok kasus jarak kehamilan yang anak pertama sebanyak 12 orang (20\%), yang memiliki jarak kehamilan $<2$ tahun sebanyak 2 orang $(3,3 \%)$ dan yang memiliki jarak 
Journal of Healthcare Technology and Medicine Vol. 5 No. 2 Oktober 2019

Universitas Ubudiyah Indonesia

e-ISSN : 2615-109X

kehamilan $\geq 2$ tahun sebanyak 16 orang $(26,7 \%)$. Pada kelompok kontrol jarak kehamilan yang anak pertama sebanyak 7 orang $(11,7 \%)$, yang memiliki jarak kehamilan $<2$ tahun sebanyak 1 orang $(1,7 \%)$ dan yang memiliki jarak kehamilan $\geq 2$ tahun sebanyak 22 orang $(36,6 \%)$.

Tabel 1. Distribusi Frekuensi Faktor-faktor Yang Berhubungan Dengan Risiko Kematian Bayi 0-28 Hari Di Kabuopaten Bireuen Tahun 2019

\begin{tabular}{|c|c|c|c|c|}
\hline \multirow{3}{*}{ Analisis Univariat } & \multicolumn{4}{|c|}{ Kematian Bayi 0-28 Hari } \\
\hline & \multicolumn{2}{|c|}{ Kasus } & \multicolumn{2}{|c|}{ Kontrol } \\
\hline & $\mathbf{n}$ & $\%$ & $\mathbf{n}$ & $\%$ \\
\hline \multicolumn{5}{|l|}{ Umur Ibu } \\
\hline 20-35 tahun & 23 & 38,3 & 29 & 48,3 \\
\hline$>35$ tahun & 7 & 11,7 & 1 & 1,7 \\
\hline \multicolumn{5}{|l|}{ Paritas } \\
\hline Primipara & 12 & 20 & 7 & 11,7 \\
\hline Multipara & 15 & 25 & 20 & 33,3 \\
\hline Grande Multivariat & 3 & 5 & 3 & 5 \\
\hline \multicolumn{5}{|l|}{ Jarak Kehamilam } \\
\hline Anak Pertama & 12 & 20 & 7 & 11,7 \\
\hline$<2$ tahun & 2 & 3,3 & 1 & 1,7 \\
\hline$\geq 2$ tahun & 16 & 26,7 & 22 & 36,6 \\
\hline
\end{tabular}

Analisis Bivariat : Berdasarkan tabel 2 dapat dilihat hasil penelitian hubungan umur Ibu dengan kematian bayi 0-28 hari menunjukkan bahwa dari 52 orang yang berumur 20-35 tahun, yang mengalami kematian bayi sebanyak 23 orang $(38,3 \%)$ dan dari 8 orang yang berumur $>35$ tahun yang mengalami kematian bayi sebanyak 7 orang $(11,7 \%)$. Berdasarkan hasil analisis uji statistik Chi-Square diperoleh nilai $p$-value $=0,052>\alpha 0,05$, yang berarti Ho diterima dan Ha ditolak maka dapat disimpulkan bahwa tidak ada hubungan umur ibu dengan kematian bayi 0-28 hari. Berdasarkan analisis Odds Ratio (OR) diperoleh nilai Lower Limit- Upper Limit (LL-UL) sebesar 0,113 (95\% CI) = (0,013-0,988), menunjukkan bahwa umur ibu tidak berisiko mengalami kematian bayi 0-28 hari.

Berdasarkan hasil penelitian hubungan paritas dengan kematian bayi 0-28 hari menunjukkan bahwa dari 19 orang yang primipara, yang mengalami kematian bayi sebanyak 12 orang (20\%), dari 35 orang yang multipara yang mengalami kematian bayi sebanyak 15 orang $(25 \%)$. Dan dari 6 orang yang grande multipara yang mengalami kematian bayi 0-28 hari sebanyak 3 orang (5\%). Berdasarkan hasil analisis uji statistik Chi-Square diperoleh nilai $p$-value $=0,362>\alpha 0,05$, yang berarti Ho diterima dan Ha ditolak maka dapat disimpulkan bahwa tidak ada hubungan paritas dengan kematian bayi 0-28 hari. Berdasarkan analisis Odds 
Journal of Healthcare Technology and Medicine Vol. 5 No. 2 Oktober 2019

Universitas Ubudiyah Indonesia

e-ISSN : 2615-109X

Ratio (OR) diperoleh nilai Lower Limit- Upper Limit (LL-UL) sebesar 1,581 (95\% CI) = (0,674-3,707), menunjukkan bahwa paritas berisiko 1 kali mengalami kematian bayi 0-28 hari.

Berdasarkan hasil penelitian hubungan jarak kehamilan dengan kematian bayi 0-28 hari menunjukkan bahwa dari 19 orang yang anak pertama, yang mengalami kematian bayi sebanyak 12 orang $(20 \%)$, dari 3 orang yang jarak kehamilan $<2$ tahun yang mengalami kematian bayi sebanyak 2 orang (3,3\%). Dan dari 38 orang yang jarak kehamilan $\geq 2$ tahun yang mengalami kematian bayi 0-28 hari sebanyak 16 orang (26,7\%). Berdasarkan hasil analisis uji statistik Chi-Square diperoleh nilai $p$-value $=0,273>\alpha 0,05$, yang berarti Ho diterima dan Ha ditolak maka dapat disimpulkan bahwa tidak ada hubungan jarak kehamilan dengan kematian bayi 0-28 hari. Berdasarkan analisis Odds Ratio (OR) diperoleh nilai Lower Limit- Upper Limit (LL-UL) sebesar 1,553 (95\% CI) = (0,882-2,737), menunjukkan bahwa jarak kehamilan berisiko 1 kali mengalami kematian bayi 0-28 hari.

Tabel 2. Hubungan Umur Ibu, Paritas, Jarak Kehamilan Dengan Kematian Bayi 0-28 Hari di Kabupaten Bireuen Tahun 2019

\begin{tabular}{|c|c|c|c|c|c|c|c|c|}
\hline \multirow{3}{*}{ Analisis Bivariat } & \multicolumn{4}{|c|}{ Kematian Bayi 0-28 Hari } & \multirow{3}{*}{$\mathbf{N}$} & \multirow{3}{*}{$\begin{array}{c}\text { p- } \\
\text { Value }\end{array}$} & \multirow{3}{*}{ OR } & \multirow{3}{*}{ (CI95\%) } \\
\hline & \multicolumn{2}{|c|}{ Kasus } & \multicolumn{2}{|c|}{ Kontrol } & & & & \\
\hline & $\mathbf{n}$ & $\%$ & n & $\%$ & & & & \\
\hline \multicolumn{9}{|l|}{ Umur Ibu } \\
\hline 20-35 tahun & 23 & 38,3 & 29 & 48,3 & 52 & \multirow{2}{*}{0,052} & \multirow{2}{*}{0,113} & \multirow{2}{*}{$(0,013-0,988)$} \\
\hline$>35$ tahun & 7 & 11,7 & 1 & 1,7 & 8 & & & \\
\hline \multicolumn{9}{|l|}{ Paritas } \\
\hline Primipara & 12 & 20 & 7 & 11,7 & 19 & \multirow{3}{*}{0,362} & \multirow{3}{*}{1,581} & \multirow{3}{*}{$(0,674-3,707)$} \\
\hline Multipara & 15 & 25 & 20 & 33,3 & 35 & & & \\
\hline Grande Multipara & 3 & 5 & 3 & 5 & 6 & & & \\
\hline \multicolumn{9}{|l|}{ Jarak Kehamilan } \\
\hline Anak Pertama & 12 & 20 & 7 & 11,7 & 19 & \multirow{3}{*}{0,273} & \multirow{3}{*}{1,553} & \multirow{3}{*}{$(0,882-2,737)$} \\
\hline$<2$ tahun & 2 & 3,3 & 1 & 1,7 & 3 & & & \\
\hline$\geq 2$ tahun & 16 & 26,7 & 22 & 36,7 & 38 & & & \\
\hline
\end{tabular}

\section{PEMBAHASAN}

Hubungan Umur Ibu dengan Kematian Bayi 0-28 Hari : Dari hasil uji chi square dengan tingkat kepercayaan 95\% $(\alpha=0,05)$ hasil perhitungan menunjukkan tidak ada hubungan antara faktor umur ibu dengan kematian bayi 0-28 hari di Kabupaten Bireuen dengan nilai p $(0,052)>\alpha(0,05)$ berarti Ha ditolak dan Ho diterima. Adapun nilai OR (CI95\%=0,113) yang bermakna umur ibu tidak menjadi faktor risiko kematian bayi 0-28 hari. 
Umur dibawah <20 tahun, rahim dan panggul sering kali belum tumbuh mencapai ukuran dewasa. Akibatnya, ibu hamil pada usia itu mungkin mengalami persalinan lama/macet atau gangguan lainnya karena ketidaksiapan ibu untuk menerima tugas dan tanggung jawab sebagai orang tua, ibu dianjurkan hamil pada usia antara 20-35 tahun. Pada usia ini ibu sudah lebih siap secara jasmani dan kejiwaan. Pada umur 35 tahun atau lebih, kesehatan ibu sudah menurun, akibatnya ibu hamil pada usia itu mempunyai anak cacat, persalinan lama dan perdarahan (Kemenkes RI, 2011).

Umur merupakan salah satu faktor yang dapat menggambarkan kematangan seseorang baik secara fisik, psikis maupun sosial. Semakin bertambahnya umur umur seseorang maka bertambah pula pengetahuan yang didapat. Banyak wanita yang hamil >35 tahun berhasil menjalankan kehamilan yang sehat dan melahirkan bayinya dengan selamat. Risiko terjadinya kesakitan dan kematian pada umur yang lebih tua dapat diminimalisir dengan perawatan kehamilan yang teratur, informasi tentang kehamilan dan persalinan yang lebih lengkap tentang tanda-tanda bahaya kehamilan dan kehamilan risiko tinggi, serta pertolongan tenaga kesehatan yang berkompeten akan membantu ibu untuk tetap sehat pada masa kehamilan, persalinan dan nifas (Prabamurti, 2006 dalam Effendi, 2013).

Menurut Penelitian yang dilakukan oleh Jusuf S. Effendi dkk Tahun 2013, yang berjudul Hubungan Umur Ibu, Paritas Dan Penolong Persalinan Dengan Kematian Neonatal Diwilayah Kerja Puskesmas Kabupaten Banjarnegara. Penelitian ini menggunakan rancangan case control dengan pendekatan retrospektif. Data kematian neonatal diperoleh dari catatan medik. Subjek penelitian adalah seluruh ibu yang melahirkan dan anaknya mengalami kematian usia 0-28 hari. Besar sampel yang digunakan adalah 68 responden untuk masingmasing kelompok kasus dan kontrol. Menunjukkan bahwa umur ibu tidak berhubungan dengan kematian neonatal ( $\mathrm{p}>0,05)$.

Menurut asumsi peneliti, faktor Umur Ibu tidak berhubungan dengan risiko kematian bayi 0-28 hari dikarenakan mayoritas umur ibu berada pada kategori 20-35 tahun dimana usia tersebut menjadi usia ideal untuk hamil dan melahirkan dan rahim sudah mampu menjalankan fungsinya dengan baik, sehingga sangat kecil kemungkinan terjadinya risiko kematian bayi 028 hari. Dan pada umur 20-35 tahun ibu sudah banyak yang memahami faktor-faktor yang dapat berhubungan dengan kematian bayi 0-28 hari, sehingga langkah-langkah yang diambil sudah sempurna. 
Journal of Healthcare Technology and Medicine Vol. 5 No. 2 Oktober 2019

Universitas Ubudiyah Indonesia

e-ISSN : 2615-109X

Hubungan Paritas dengan Kematian Bayi 0-28 Hari : Dari hasil uji chi square dengan tingkat kepercayaan 95\% $(\alpha=0,05)$ hasil perhitungan menunjukkan tidak ada hubungan antara faktor paritas ibu dengan kematian bayi 0-28 hari di Kabupaten Bireuen dengan nilai p $(0,362)>\alpha(0,05)$ berarti Ha ditolak dan Ho diterima. Adapun nilai OR (CI95\%=1,581) yang bermakna Paritas menjadi faktor risiko kematian bayi 0-28 hari dan Paritas berisiko 1 kali lebih besar terjadi kematian bayi 0-28 hari.

Menurut Kamus Saku Mosby (Kedokteran, Keperawatan dan Kesehatan), paritas merupakan klasifikasi perempuan berdasarkan jumlah bayi lahir hidup dan lahir mati yang dilahirkannya pada umur kehamilan lebih dari 20 minggu. Pada masa kehamilan rahim ibu teregang oleh adanya janin. Apabila terlalu sering melahirkan, rahim akan semakin lemah. Apabila ibu telah melahirkan 3 anak atau lebih, perlu diwaspadai adanya gangguan pada waktu kehamilan, persalinan dan nifas (Kemenkes RI, 2011).

Menurut Penelitian yang dilakukan oleh Siti Malati Umah Tahun 2014, yang berjudul Determinan Kematian Neonatal di Daerah Rural Indonesia. Sumber data penelitian adalah Survey Demografi dan Kesehatan Indonesia 2012 dengan desain penelitian cross sectional study dan analisis statistik menggunakan uji chi square. Hasil penelitian didapatkan faktor paritas ada hubungan dengan kematian neonatal $(0,033)$.

Hubungan Jarak Kehamilan dengan Kematian Bayi 0-28 Hari : Dari hasil uji chi square dengan tingkat kepercayaan 95\% $(\alpha=0,05)$ hasil perhitungan menunjukkan tidak ada hubungan antara faktor Jarak Kehamilan dengan kematian bayi 0-28 hari di Kabupaten Bireuen dengan nilai $\mathrm{p}(0,273)>\alpha(0,05)$ berarti Ha ditolak dan $\mathrm{H}_{0}$ diterima. Adapun nilai OR $(\mathrm{CI} 95 \%=1,553)$ yang bermakna Jarak Kehamilan menjadi faktor risiko kematian bayi 0-28 hari dan jarak kehamilan Anak Pertama berisiko 1 kali lebih besar terjadi kematian bayi 0-28 hari.

Jarak kehamilan menurut USAID (2007) adalah rentang waktu antar dua kelahiran hidup yang berurutan, sedangkan menurut kamus istilah Kependudukan dan Keluarga Berencana (KKB) tahun 2011 jarak waktu periode antara dua kelahiran hidup yang berurutan dari seorang wanita. Kehamilan yang berakhir dengan keguguran tidak diperhitungkan, karena keguguran tidak termasuk dalam definisi kelahiran. Menurut SDKI 2012, jarak kehamilan adalah jarak antar kelahiran anak dengan anak sebelumnya yang lahir hidup. Jarak 
Journal of Healthcare Technology and Medicine Vol. 5 No. 2 Oktober 2019

Universitas Ubudiyah Indonesia

e-ISSN : 2615-109X

kehamilan yang pendek akan menyebabkan seorang ibu belum cukup untuk memulihkan kondisi tubuhnya setelah melahirkan.

Apabila jarak kehamilan dengan anak sebelumnya kurang dari 2 tahun, rahim dan kesehatan ibu belum pulih dengan baik. Kehamilan dalam keadaan ini perlu diwaspadai karena kemungkinan pertumbuhan janin kurang baik, mengalami persalinan yang lama atau perdarahan (Kemenkes RI, 2011).

Menurut penelitian yang dilakukan oleh Noorhalimah tahun 2015 dengan judul Faktor-Faktor Yang Berhubungan Dengan Kematian Neonatal di Kabupaten Tepin. Metode penelitian yang digunakan adalah studi Analitik dengan metode observasional dan pendekatan cross sectional, adapun sampel dari penelitian ini adalah seluruh neonatus mati di Kabupaten Tapin yaitu 56 kasus. Metode analisis menggunakan uji chi-square pada tingkat kemaknaan 95\%. Hasil penelitiannya adalah jarak kehamilan menunjukkan nilai $\mathrm{P}=0,359>0,05$ yang artinya tidak terdapat hubungan yang bermakna antara kematian neonatal dengan jarak kehamilan.

Menurut asumsi peneliti, faktor Jarak Kehamilan ibu tidak berhubungan dengan risiko kematian bayi 0-28 hari dikarenakan mayoritas jarak kehamilan ibu berada pada kategori $\geq 2$ Tahun, dimana ibu sudah memahami faktor-faktor yang berhubungan dengan risiko kematian bayi 0-28 hari, sehingga ibu menjaga jarak antar kehamilan berikutnya.

\section{KESIMPULAN}

Berdasarkan hasil penelitian maka dapat disimpulkan sebagai berikut: tidak ada hubungan yang signifikan antara umur ibu, paritas, jarak kehamilan dengan kematian bayi 028 hari di Kabupaten Bireuen tahun 2019, dan umur ibu tidak berisiko terhadap kematian bayi 0-28 hari sementara paritas dan jarak kehamilan berisiko masing-masing 1 kali terhadap kematian bayi 0-28 hari.

\section{SARAN}

Diharapkan kepada tenaga kesehatan untuk dapat melakukan kegiatan penyuluhan tentang faktor-faktor yang berhubungan dengan kematian bayi 0-28 hari sehingga dapat menurunkan angka kematian bayi. 
Journal of Healthcare Technology and Medicine Vol. 5 No. 2 Oktober 2019

Universitas Ubudiyah Indonesia

e-ISSN : 2615-109X

\section{DAFTAR PUSTAKA}

Adelina, Fitri, 2017. Pengaruh Jarak Kelahiran Terhadap Kematian Bayi di Indonesia, Filipina dan Kamboja. Jurnal Epidemiologi Kesehatan. Vol. 1 No. 2

Ainindya, Pasca Rachmadiani, 2018. Faktor-Faktor Risiko Kematian Bayi Usia 0-28 Hari di $R S D$ dr. Soebandi Kabupaten Jember.Jurnal Agromedicine and medical sciences. Vol. 4. No. 2

Bagus, 2008. Demografi Umum. Pustaka Pelajar, Yogyakarta

BKKBN, 2008. Perkawinan Muda di Kalangan Perempuan. Pusat Penelitian dan Pengembangan Kependudukan

Dinas Kesehatan Aceh, 2017. Profil Kesehatan Aceh.

Dinas Kesehatan Kabupaten Bireuen, 2018. Laporan Kematian Bayi Kabupaten Bireuen Tahun 2018. DINKES Bireuen.

Data Statistik Indonesia, 2013. Angka Kematian Bayi. Statistik Indonesia, Jakarta.

Efriza, 2007. Determinan Kematian Neonatal Dini di RSUD Dr. Achmad Mochtar Bukittinggi. Jurnal Kesehatan. Vol. 1 No.2

Iman, 2016. Panduan Penyusunan Karya Tulis Ilmiah Bidan Kesehatan. Cita Pusaka: Medan.

$\longrightarrow$ 2012. Pemanfaatan SPSS Dalam Penelitian Bidang Kesehatan. Cita Pusaka, Medan.

Kemenkes RI, 2017. Profil Kesehatan Indonesia. www.kemenkes.go.id

Latifah, Noor, 2012. Hubungan Frekuensi Kunjungan ANC Selama Kehamilan dengan Kejadian Kematian Neonatal. FKM Universitas Indonesia.

Mardjan, 2014. Pengaruh Kecemasan Pada Kehamilan Primipara Remaja. Nuha Medika, Yogyakarta.

Manuaba, 2007. “Gawat Darurat Obgin Sosial untuk Profesi Bidan”. EGC, Jakarta

Mahmudah, 2011. Faktor Ibu dan Bayi yang Berhubungan dengan Kejadian Kematian Perinatal, Jurnal Kesehatan Masyarakat.

Muslihatun, 2010. Asuhan Neonatus Bayi dan Balita. Fitramaya, Yogyakarta

Notoatmodjo, 2012. Metodologi Penelitian Kesehatan. Rineka Cipta, Jakarta

Noorhalimah, 2015. Faktor-Faktor Yang Berhubungan Dengan Kematian Neonatal Di Kabupaten Tapin. Jurnal Kesehatan Masyarakat. Vol.2 No.2

Padila, 2014. Keperawatan Maternitas. Nuha Medika, Yogyakarta

Prabamurti, 2006. Analisis Faktor Risiko Kematian Neonatal di Kecamatan Losari Kabupaten Brebes Tahun 2006. Jurnal Promosi Kesehatan Indonesia

Prawirohardjo, 2008. Buku Acuan Nasional Pelayanan Kesehatan Maternal dan Neonatal. YBP-SP, Jakarta

Qubro, Dinah Zhafira, 2018. Hubungan Antara Usia Dan Paritas Ibu Dengan Kejadian Abortus Di Rumah Sakit Abdul Moeloek Bandar Lampung. Program Studi Pendidikan Dokter. Universitas Lampung

Rohan, 2013. Kesehatan Reproduksi. Nuha Medika, Yogyakarta

Subakti, 2013. Kupas Tuntas Seputar Kehamilan. PT AgroMedia Pustaka, Jakarta Selatan

Stedman, 2005. Stedman's Medical Dictionary 28th. ed. Baltimore: Lippicott Williams and Wilkins.

Walyani, 2015. Asuhan Kebidanan Kegawatdaruratan Maternal \& Neonatal. Pustaka Baru Press, Yogyakarta

Wandira, 2012. Faktor Penyebab Kematian Bayi di Kabupaten Sidoarjo. Jurnal Biometrika dan Kependudukan

WHO, 2015. Global References list of 100 Core Health Indicators 